\title{
Informationsflow i forfald
}

af bevaringschef Jonas Palm

Et verdensomspændende problem for nutidens arkiver og biblioteker er bevaringen af dokumenter og bøger, skrevet eller trykt på papir, som ind imellem er så dårligt, at det falder fra hinanden, lige for øjnene af os. Årsagen til dette kan man finde i menneskets drift imod at formidle sine tanker, både i samtiden og i et tidsperspektiv. Formidlingen har dog været afhængig af materialet som 'bar' skriften. Udviklingen fra at male på hule-vægge, over at presse kiler i lertavler og at skrive på papyrus, til dagens masseproduktion af papir, har været baseret på at øge det, vi i dag kalder informationsflow'et, og dette har på sin side været afhængig af muligheden for at mangfoldiggøre og sprede. Først efter at papiret var blevet opfundet havde man et produkt, som både var let at masseproducere og velegnet til spredning.

Papirets historie strækker sig tilbage til år 105 e. Kr., da kineseren Tsai Lun meddelte kejseren af Kina, at papiret var opfundet. Da papiret næsten 1000 år senere kom til Europa, regnede man det for et sekunda-produkt, sammenlignet med pergamentet, som ansås for at være overlegent med hensyn til kvalitet. Papiret fremstilledes af klude, først og fremmest af hamp og linned og senere bomuld, som blev sønderdelt og blandet med vand til en papirmasse. De deri opløste fibre opfangedes af en netramme, og når vandet var drevet ud, var der en fibermåtte tilbage. Denne blev presset, limet på overfladen med gelatine og tørret, hvorefter papiret var klar til brug. Dette håndgjorte papir, klude-papir, af rene cellulosefibre, havde en meget fin langtidsholdbarhed. Det papir, som idag benævnes arkivpapir, det vil sige det papir, der har den bedste langtidsholdbarhed, er en moderne udgave af det gamle håndgjorte kludepapir, men af bomuldsfibre, først og fremmest. (Fig. 1).

Først med bogtrykkunstens gennembrud i 1400-tallet øgedes papirfrem- 


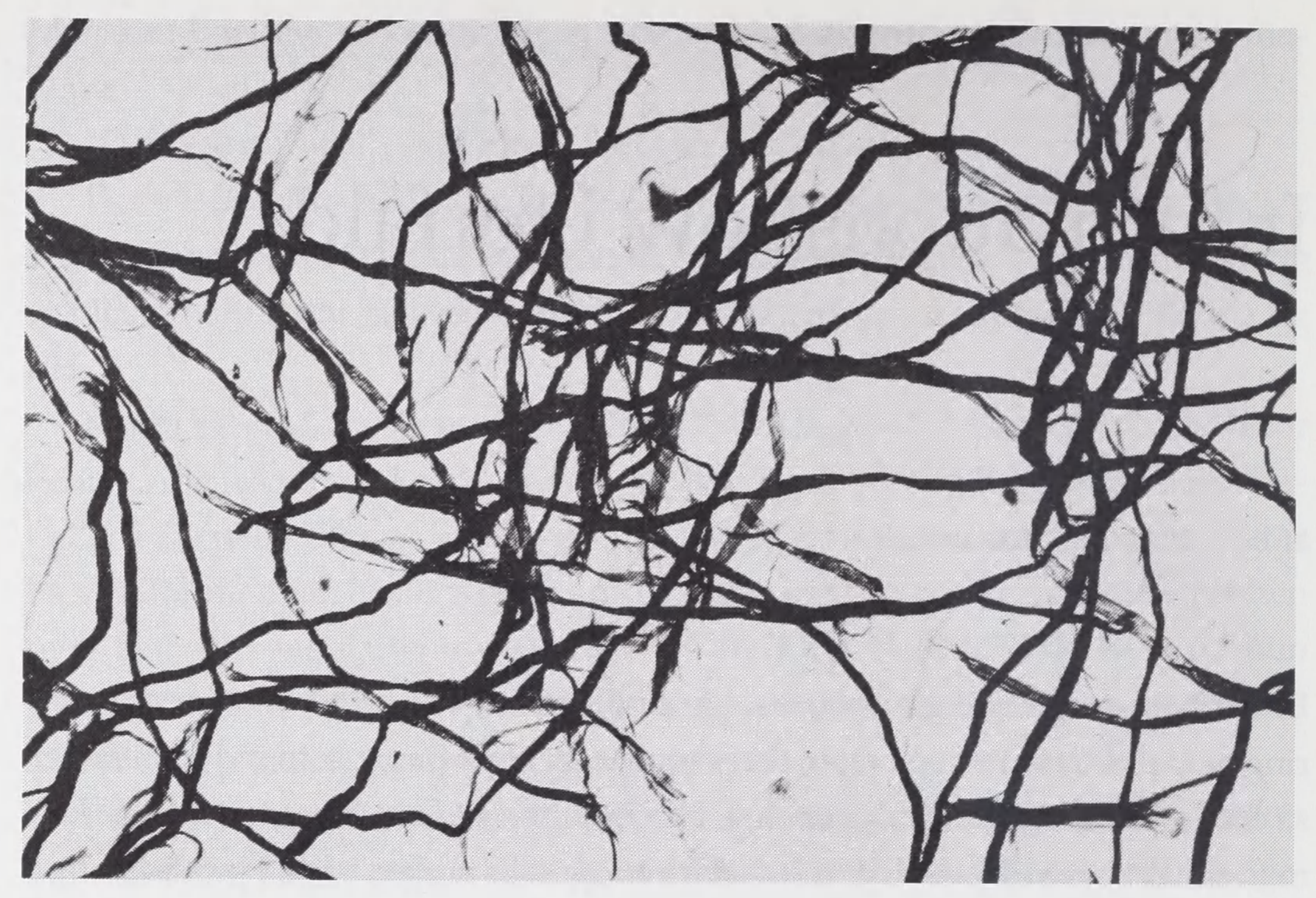

Fig. 1. Bomuldsfibre.

fremstillingen markant i Europa. Mulighederne for at mangfoldiggøre tekst på et relativt billigt materiale gjorde, at efterspørgslen på papir øgedes hele tiden. Allerede i 1600-tallet ledte dette til mangel på råvarer og i bl.a. England forbød man 1666 at anvende al stof, undtagen uld, til ligklæder. Øvrigt klædemateriale, som kasseredes, skulle anvendes som råvarer til papir. Således sparede man ca. 100.000 kg klude om året, bare i England. Råvaremanglen fortsatte dog med at stige trods lignende foranstaltninger andre steder i Europa og Nordamerika. Der blev lavet forsøg med at fremstille papir af alternative råvarer, og 1719 foreslog den franske videnskabsmand Réaumur, at man skulle anvende træfibre til fremstilling af papir, men først omkring 1850 kom en sådan produktion i gang.

Træslibemasse, eller mekanisk masse, blev fremstillet ved at nedslibe træstammer. Man fik en uren og kortfibret masse - billigt, hurtigt og meget - når træslibefibrene blev sønderslidt ved slibningen og øvrige træbestanddele fulgte med i massen (Fig. 2). Denne urene masse indeholdt emner, først og fremmest lignin, som initierede sure nedbrydningsprocesser der både nedbrød og misfarvede papiret. Papiret fik en meget ringe langtidsholdbarhed. Træslib har dels været den eneste råvare i papir men er også ofte blevet blandet med andre fibertyper. Disse papirtyper kaldes almindeligvis for træholdige papirer.

Som en direkte følge af, at produktionen af håndgjort papir ikke dækkede 


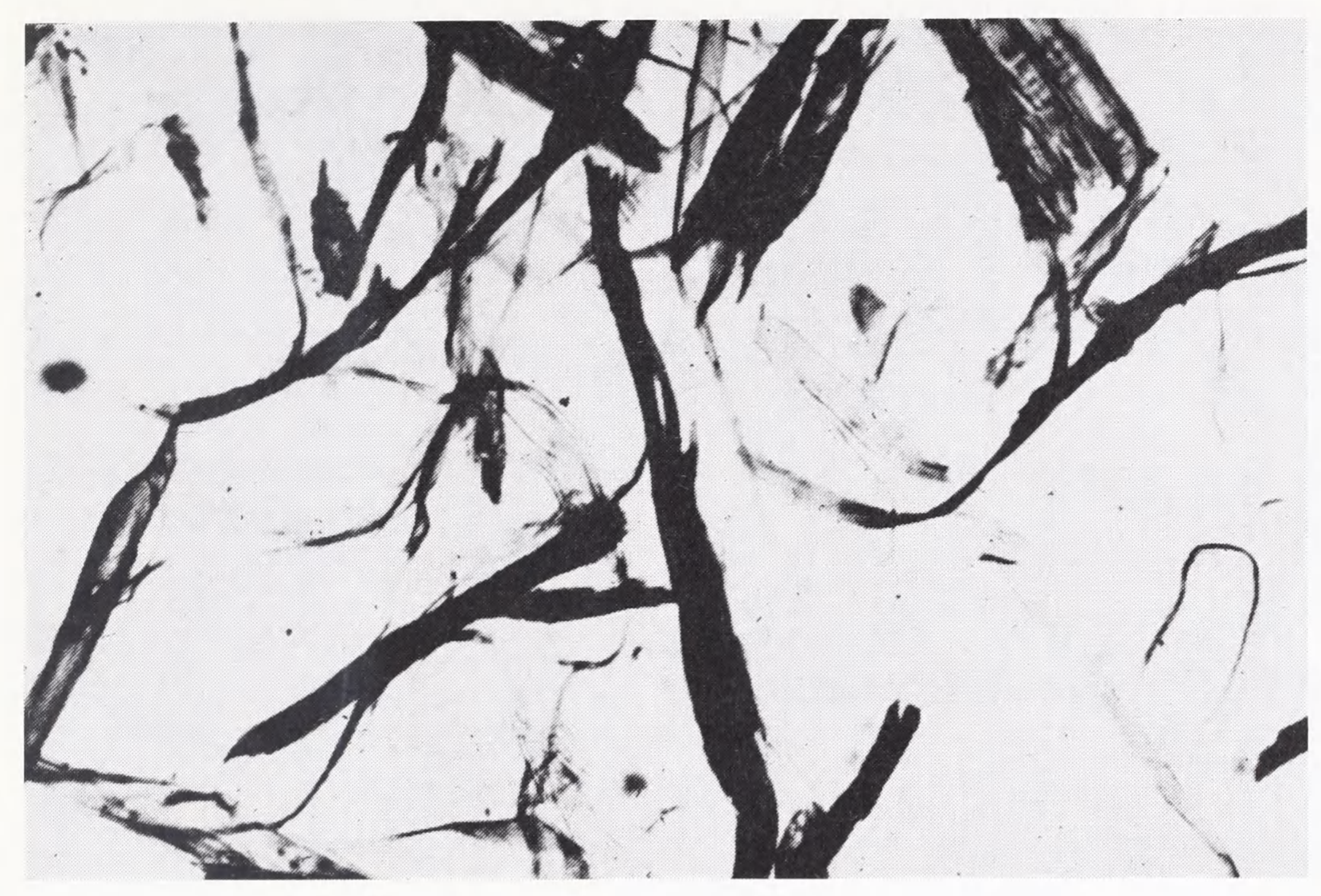

Fig. 2. Træslibfibre.

markedets behov, introduceredes papirmaskinen i begyndelsen af 1800-tallet. Hermed var man af procestekniske grunde tvunget til, fra tidligere at have limet papirarkene med gelatine, at gå over til at blande limen direkte i papirmassen. Limen bestod af alun og harpikssyrer, såkaldt alunharpiks- eller surlim. Da gelatinen erstattedes af surlimen tilførtes kemikalier som kunne aktivere sure reaktioner i papiret, hvilket på sin side nedbrød papirfibrene. Langtidsholdbarheden forringedes dermed og når man fyrre år senere begyndte at anvende træslibemasse til maskinfremstillet papir, fik man et papir med både surlimens og den urene træslibemasses nedbrydende egenskaber. Dette resulterede i et produkt med ekstremt dårlig langtidsholdbarhed.

Efter at træslibemassen introduceredes i papirfremstillingen over en bred front, begyndte man at forsøge at koge træflis i en kemisk proces, sur eller alkalisk, for at fritlægge cellulosefibrene (Fig. 3). Efterhånden udvikledes dette til sulfi- og sulfat-metoderne. Dermed fik man en såkaldt kemisk masse med længere fibre, som var stort set mekanisk ubearbejdet. Gennem blegning reduceredes restprodukterne og massen blev lys. Disse masser surlimedes dog, hvorved langtidsholdbarheden forringedes. Den varierer ved surlimet finpapir men er generelt bedre end ved træholdigt papir. Normalt kaldes bleget papir af kemisk masse, 


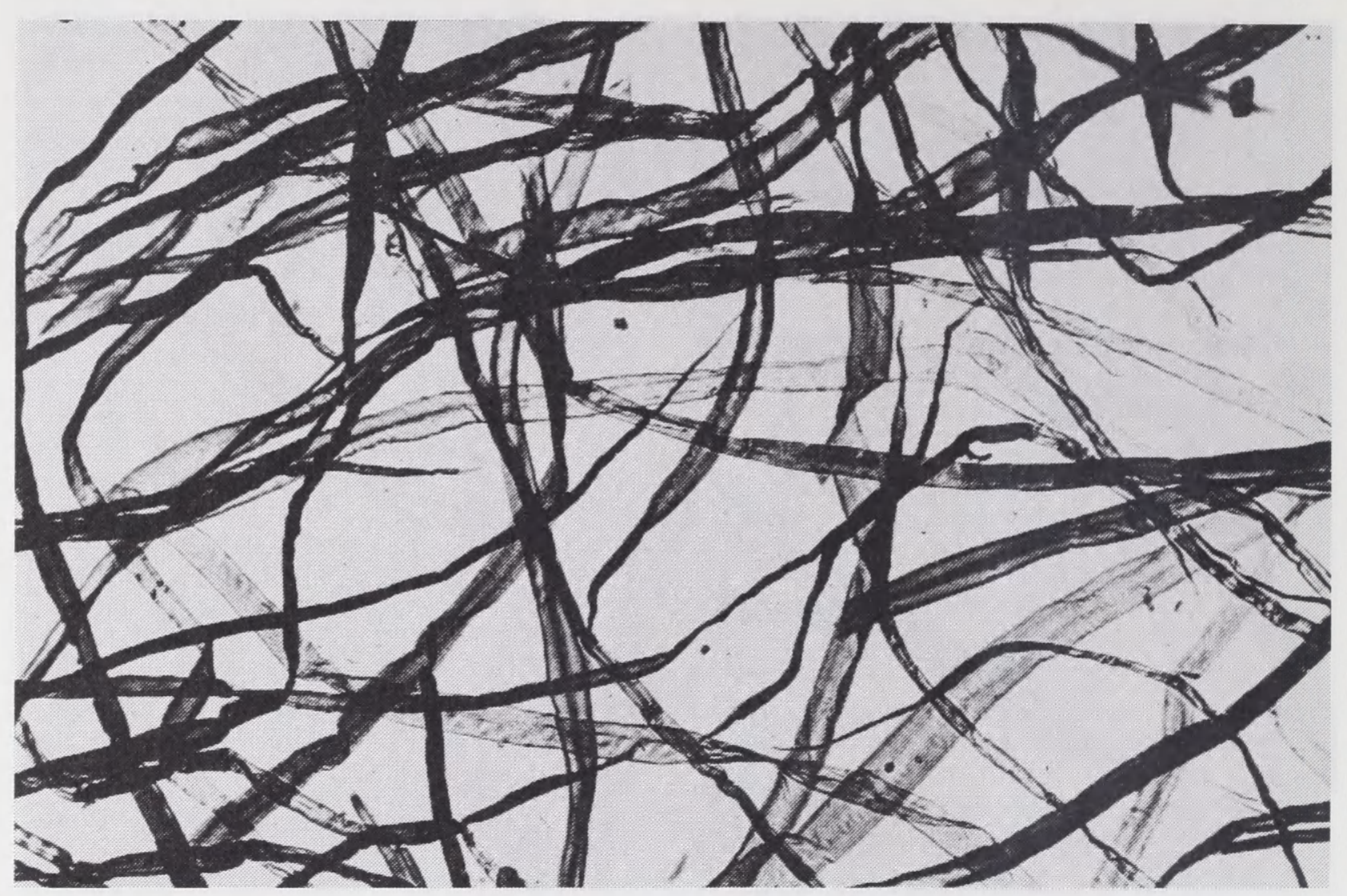

Fig. 3. Nåletræsfibre i en kemisk masse. Sammenlign med karakteren af træslib-fibrene i fig. 2.

beregnet til skrift og tryk, for finpapir. I dag findes et antal forskellige processer til fremstilling af papirmasse.

Fra 1870'erne og frem fremstilledes hovedsagelig tre forskellige slags papir til skrift og tryk: neutrallimet kludepapir, surlimet træholdigt papir og surlimet finpapir.

Træholdigt papir blev først og fremmest brugt til billige masseprodukter som aviser, billigbøger og reklametryksager, mens finpapir oftest anvendtes til skrivepapir og til bog- og tidsskriftproduktion med højere kvalitetskrav. Kludepapir har været et kvalitetspapir, hvis anvendelsesområder var dikteret deraf.

Siden 1980'ernes slutning er flere og flere finpapirsværker gået over til at neutrallime papiret. Dermed får man et papir med betydeligt bedre langtidsholdbarhed end det surlimede.

\section{Nedbrydning af papir}

Som tidligere nævnt sætter lignin og surlim gang i kemiske reaktioner, som nedbryder papir, i første omgang gennem sur hydrolyse. Bindingerne imellem de molekyler, som opbygger en cellulosefiber, brydes af og fibrene opdeles i mindre og mindre dele, hvorved papiret bliver sprødt. Høj temperatur og luftfugtighed øger effekten i disse reaktioner (Fig. 4). 


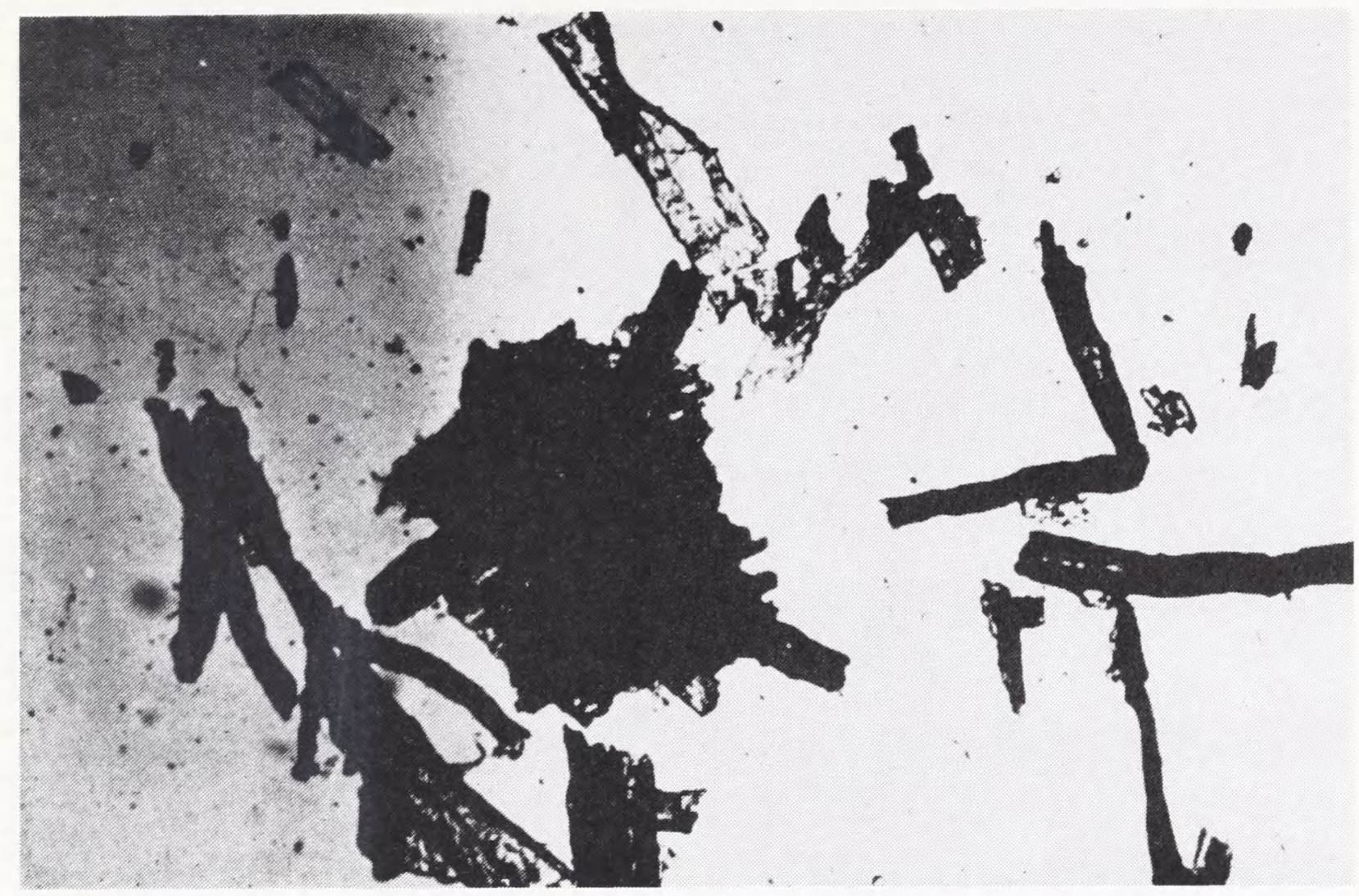

Fig. 4. Papirfibre der er nedbrudt af sur hydrolyse. Sammenlign med fig. 1, 2 og 3. Afkortningen af disse fibre skaber sprødt papir.

Denne form for nedbrydning blev dog ikke indført i arkiv- og biblioteksverdenen i forbindelse med at træholdigt surlimet papir begyndte at blive masseproduceret. Nedbrydning af ældre papir var forekommet i forbindelse med bl.a. jerngallusblæk og grønne pigmenter, baserede på kobberforbindelser. Sure forbindelser i blæk og farve aktiveredes gennem ydre klimatiske forhold hvilket resulterede i, at papiret ætsedes i stykker. (Fig. 5 og 6).

Selv kludepapir kunne udsættes for kraftig nedbrydning under ekstreme klimaforhold. Kvalitetet af dette kunne desuden variere, afhængig af, hvor det var fremstillet og fremstillingsstedets vandkvalitet. Fig. 7 viser dels hvor kraftig nedbrydningen af kludepapir kan være i et tropisk klima, dels hvor to forskellige papirtyper kan reagere forskelligt. Plancherne i dette værk fra 1700-tallet var gennemgående i nogenlunde god stand, mens tekstdelen var under stærk nedbrydning.

Allerede i 1800-tallets sidste halvdel var man opmærksom på den kraftige nedbrydningshastighed i træholdigt papir, og i 1898 forsamledes biblioteks- og arkivfolk i St. Gallen for at drøfte problemet. Ved et arkivmøde i Dresden 1899 lanceredes den første massekonserveringsmetode, zaponforsegling. Sprødt papir forsegledes med celluloselak, hvorved det fik en forstærkning. Metoden spredte sig hurtigt, men allerede efter nogle år kom der alarmrapporter om at 


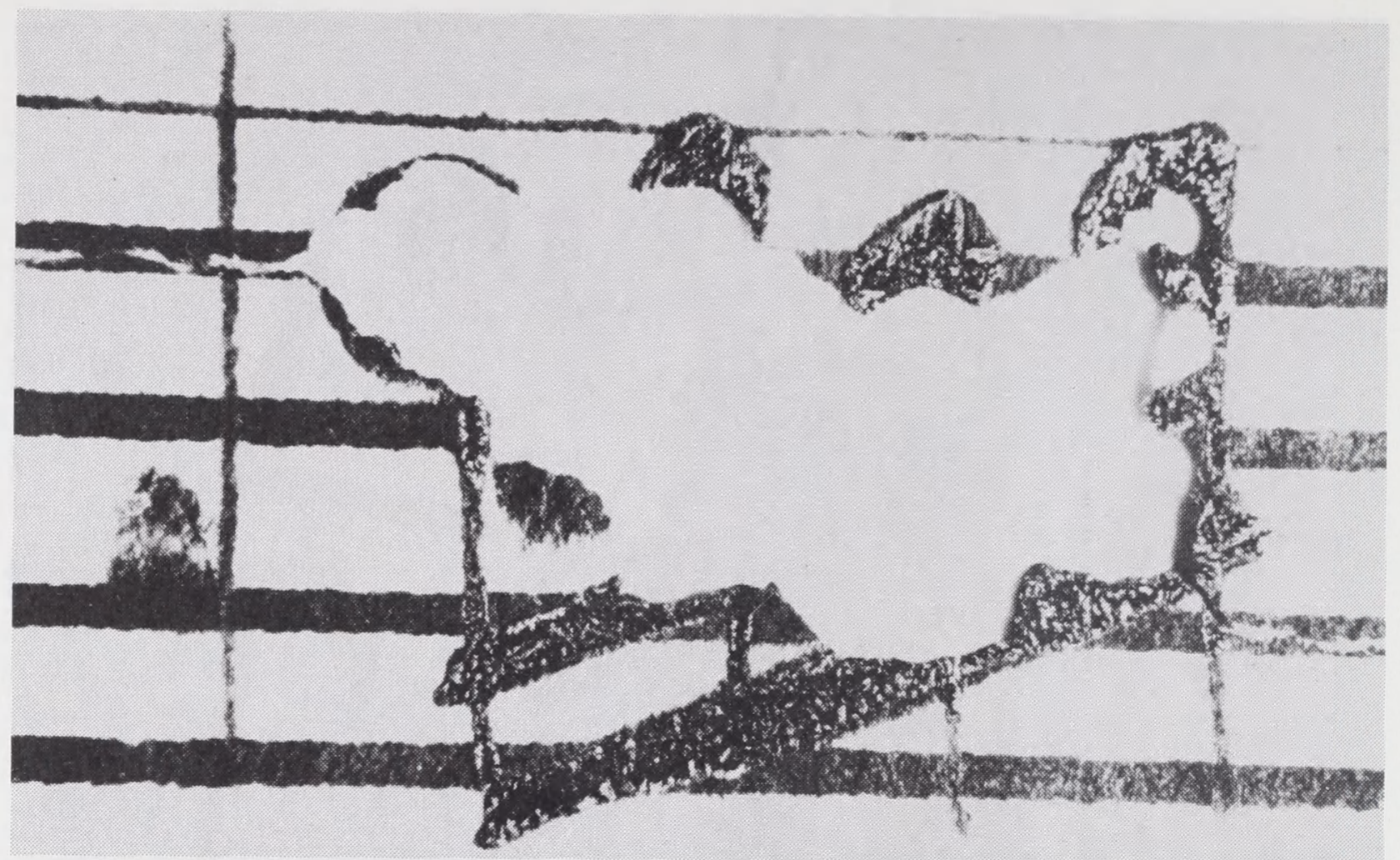

Fig. 5. Effekten af en blækætsning.

de behandlede papirer blev nedbrudt endnu hurtigere end før. Forstærkningseffekten var bare midlertidig.

\section{Massekonservering/masseafsyring i moderne tid}

Diskussionerne om hvordan man skulle redde papir med ringe langtidsholdbarhed fortsatte. Samtidig indførtes i Sverige 1907 "Normalpappersförordningen", som angav krav til papir som skulle anvendes i statslige virksomheder. Blandt andet måtte det ikke indeholde træslibemasse i de anvendelsesområder, hvor bestandigheden var vigtig. I slutningen af 1950'erne og begyndelsen af 1960'erne finansierede amerikaneren William J. Barrow forskning omkring nedbrydning af papir, hvorved man fandt, at ved at tilføre papiret en alkalisk substans - afsyring - kunne man modvirke den sure hydrolyse. Langtidsholdbarheden kunne dermed forbedres, men allerede nedbrudte fibre kunne ikke få deres oprindelige styrke tilbage. Metoderne som præsenteredes, egnede sig desuden kun for behandlingen af enkelte ark, mens behovet for at kunne afsyre store mængder dokumenter og bøger ikke kunne opfyldes.

I 1970'erne og 1980'erne er der udviklet en række af hinanden uafhængige masseafsyringsmetoder. Principperne for de mest vellykkede har været, at man imprægnerede store mængder arkivalier og bøger med gas eller væske for at deponere alkaliske substanser, som har en neutraliserende virkning i papiret. 
Fig. 6. Effekten af en kobberætsning. Den grønne kobberpigmentbaserede farve, som markerede grænserne, har ætset sig gennem papiret.

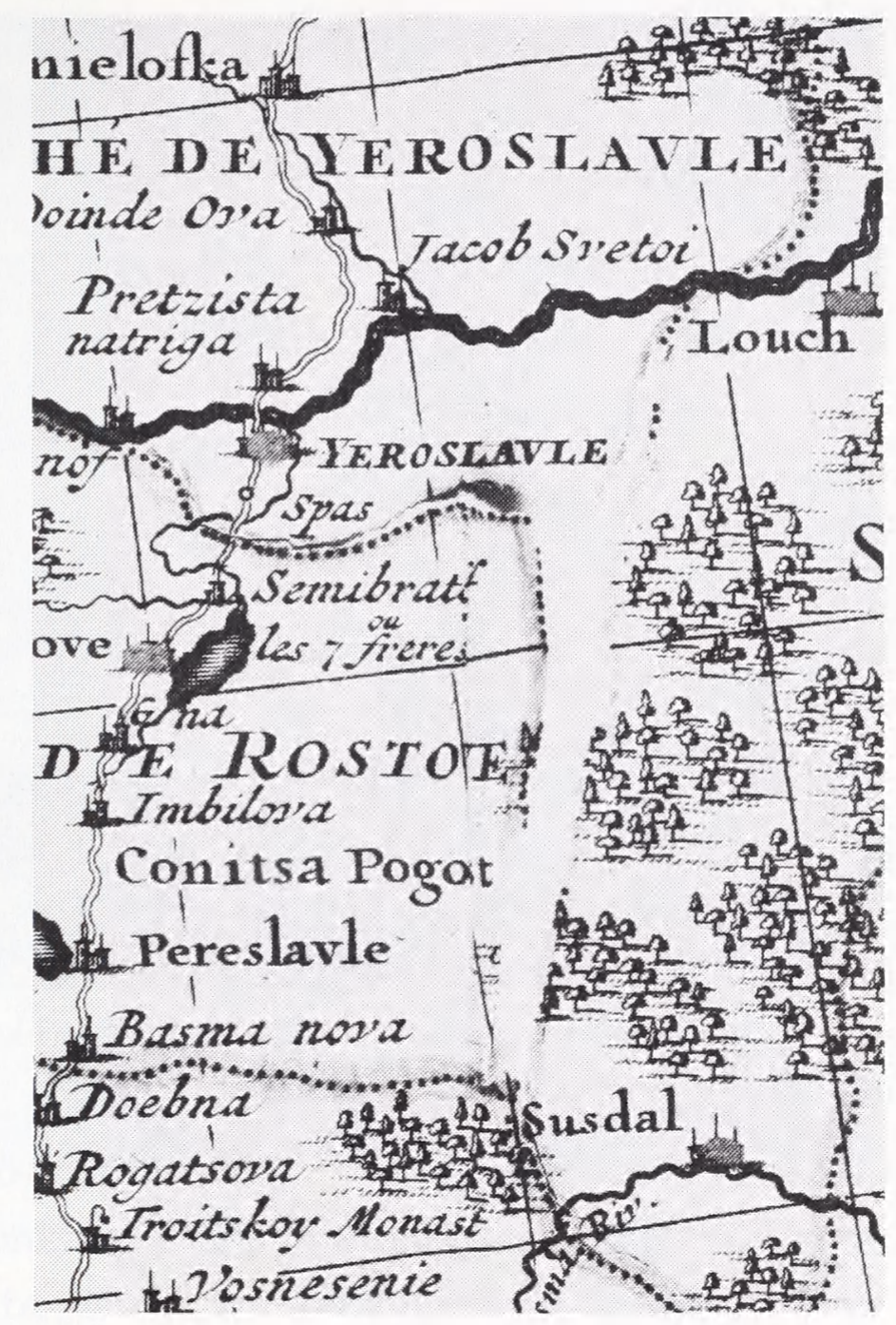

De mest kendte er Wei T'o - magnesiummetylkarbonatbaseret - (USA/Canada), DEZ - dietylzinkbaseret (USA), FMC - magnesiumbutoxytriglykolatbaseret (USA), Bookkeeper - magnesiumoxidbaseret - (USA), samt en variant af magnesiummetylkarbonatmetoden i Frankrig (Sablé). Yderligere en masseafsyringsmetode er udviklet i Tyskland (Battelle Institut) med udgangspunkt i det magnesiummetylkarbonatbaserede, men med visse kemiske ændringer.

Ingen af metoderne har vist sig at blive fuldt accepterede trods ihærdige forsøg fra fremstillernes side på at overbevise om de respektive metoders fordele. Der er store penge indblandet, dels i at etablere anlæggene, dels i selve driftsomkostningerne, som idag ligger mellem 50 og 100 kr. pr. behandlet bog. Det kongelige Bibliotek i København har ca. 5 mill. bøger. Skulle en tiendedel behandles, ville det koste ca. 37 mill. $\mathrm{kr}$.

Som tidligere nævnt indebærer afsyring udelukkende, at man forhindrer yderligere nedbrydning og ikke nogen forstærkning af papiret. Dette har British Library taget fat på og udviklede i samarbejde med University of Surrey i England en massekonserveringsmetode i 1980'erne. Metoden går ud på, at man forstærker de nedbrudte papirfibre ved på kemisk vis at implementere et poly- 


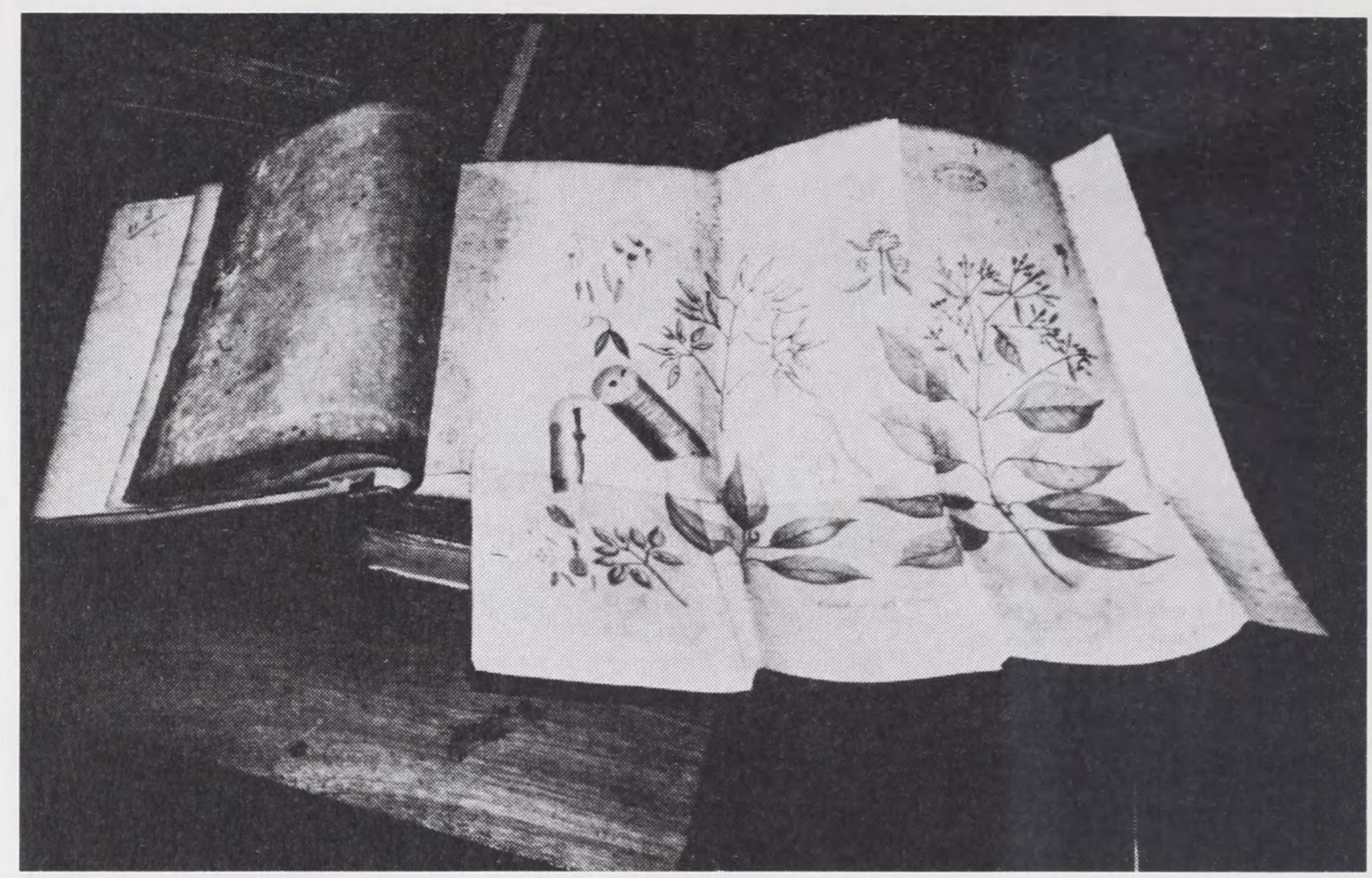

Fig. 7. De mørke ark til venstre er tekstdelen, trykt på én slags papir og den udfoldede planche til højre er trykt på en anden slags papir.

mer-net i papiret som holder de nedbrudte fibre sammen. Et problem har det dog været, at trods at papiret forbliver uforandret i størrelsen, øges vægten med op til $20 \%$. Metoden er overtaget og videreudviklet af et privat firma. Der foregår dog ingen virksomhed i stor skala med denne metode.

\section{Forskningen idag}

Et stort antal mere eller mindre omfattende projekter omkring problematikken med det papir, der falder fra hinanden, foregår fra flere sider i verden. Et af de mere dybtgående og velplanlagte er det svenske FoU-projekt for papirkonservering, som har været igang siden 1987. Projektet er et samarbejdsprojekt mellem bog- og dokumentbevarende institutioner i Sverige, hvor projektets overordnede målsætning er at redde arkivdokumenter og bøger til glæde for kommende generationers kultur- og forskningsbehov. Projektet gennemføres bl.a. i tæt samarbejde med STFI (Skogsindustrins Tekniska Forskningsinstitut). Projektet er også involveret $\mathrm{i}$ internationale projekter.

Et af projektets problemområder er bedømmelsen af de mest lovende massekonserveringsmetoder. Dette delprojekt inden for FoU-projekter er netop nu igang og forhåbentlig kommer der en rapport i 1995-96. Det, som adskiller denne gennemgang af massekonserveringsmetoder fra tidligere, er at man gennemfører hver metodeudvikling med identiske forsøgsobjekter, hvilket ikke er sket 


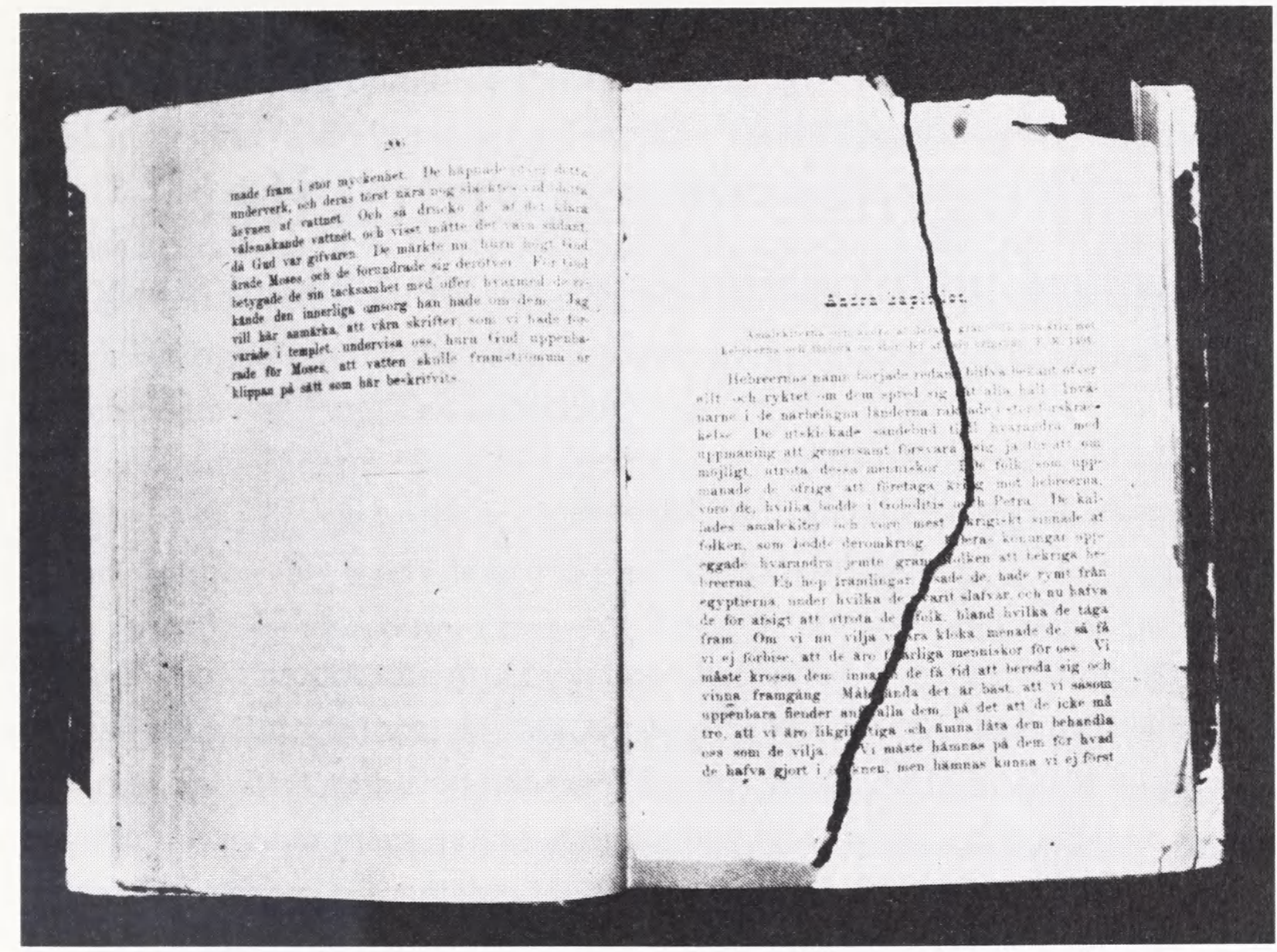

Fig. 8. Papiret i denne bog er så ødelagt at selv forsigtig håndtering kan resultere i at arkene knækker.

før. Resultatet, sammen med FoU-projektets øvrige projektresultater, turde give et klart billede af hvorledes bevaringsproblemet skal gribes an.

Det går ikke an i dag at tage stilling til hvilken massekonserveringsmetode som er den mest effektive eller om de eksisterende overhovedet er tilstrækkeligt gode. Vi kan dog forvente at få mere vederhæftig information i løbet af et par år. Indikationer findes imidlertid på at den bedste massekonservering opnås gennem optimerede opbevaringsforhold, som først og fremmest stopper kemisk nedbrydning.

I og med at dagens finpapir er blevet bedre gennem overgangen til neutrallim kan det antages, at den store mængde af objekter med selvdestruerende papir ikke kommer til at vokse i samme takt som tidligere; snarere virker det, som om kurven flader ud. En usikkerhedsfaktor ud fra et bevaringssynspunkt er dog de forskellige miljøbeskyttelsebetingede krav, som rejses mod papirproduktionen, selv på skrive- og trykpapir. 